\title{
Nasal Septum Perforation Associated to Histoplasmosis: A Retrospective Study
}

\author{
Jacinto Pineda1(D), Rommie Merino-Alado²(D), Sofia Mata-Essayag²(D), Maria Eugenia Landaeta²(D,
} Liseloth Garrido' (D), Maria del Mar Rosas $^{3}$ (D)

'Pathological Anatomy Institute “Dr. José Antonio O’ Daly”, Central University of Venezuela, Caracas, Venezuela.

2Medical Mycology Department "Dr. Dante Borelli”, Tropical Medicine Institute, Central University of Venezuela, Caracas, Venezuela.

${ }^{3}$ Otorhinolaryngology Department, Universitary Hospital of Caracas, Central University of Venezuela, Caracas, Venezuela.

Author to whom correspondence should be addressed: Professor Sofia Mata-Essayag, Medical Mycology Department "Dr. Dante Borelli”, Instituto de Medicina Tropical, Universidad Central de Venezuela, Caracas, Venezuela. Phone: +582126053881. E-mail: somae50@hotmail.com.

Academic Editors: Alessandro Leite Cavalcanti and Wilton Wilney Nascimento Padilha

Received: 20 December 2019 / Accepted: 07 May 2020 / Published: 26 May 2020

How to cite this article: Pineda J, Merino-Alado R, Mata-Essayag S, Landaeta ME, Garrido L, Rosas MM. Nasal septum perforation associated to histoplasmosis: a retrospective study. Pesqui Bras Odontopediatria Clín Integr. 2020; 20 :e5470. https://doi.org/10.1590/pboci.2020.090

\begin{abstract}
Objective: To determine the prevalence of nasal septum perforation associated to Histoplasma sp. Material and Methods: A retrospective descriptive study was conducted with patients who developed nasal septum perforation associated to histoplasmosis. The diagnosis was made based on clinical manifestations and confirmed with mycological direct examination with Giemsa stain, culture, serologic tests (immunodiffusion method), and histopathology with hematoxylin-eosin, Grocott methenamine (GMS) and Periodic AcidSchiff stain (PAS). Results: Out of 1654 medical records reviewed with diagnosis of histoplasmosis in the study period, we found 22 cases with nasal septum perforation. Autoimmune disease was present in 6 patients; all six were on immunosuppressive treatment. Two patients had HIV/AIDS, one of them had also paracoccidiodomycoses and the remaining had no apparent underlying disease or conditions. Conclusion: Physicians of endemic areas such as Venezuela, must consider this entity in the differential diagnosis with other diseases.
\end{abstract}

Keywords: Mycoses; Histoplasmosis; Immunosuppressive Agents; Acquired Immunodeficiency Syndrome. 


\section{Introduction}

Histoplasmosis is a granulomatous disease with worldwide distribution caused by Histoplasma spp. It has been described in every continent except Antarctica; frequently, it has been reported in the United States, Mexico, Central and South America. In Venezuela, this mycosis is the main fungal infection causing hospitalization and maybe death [1-3].

The global burden of histoplasmosis has been increasing, as a result of climate change, progression of HIV/AIDS, increasing number of patients with malignancies, organ transplant surgery, immunological conditions receiving immunosuppressive treatment, patients at the extremes of age as well as the detriment in the population's socioeconomic conditions (malnutrition among others) [4,5].

Usually, infection is limited by cell-mediated immunity. However, neutrophils are unable to destroy the fungus and although the macrophages are able to ingest the microorganism, they cannot destroy the fungi in tissue. Thus, infected individuals harbor yeasts that remain viable for many years. The dormant organisms pose little risk unless the patient becomes immunosuppressed as a result of the aforementioned risk factors $[4,6]$.

After inhalation of Histoplasma sp microconidia, patients develop a sub-clinical and self-limited disease that most often goes unnoticed, and may be indistinguishable from community-acquired viral or bacterial pneumonia. The infection usually resolves within 1 to 2 weeks, but in severe cases, disseminated forms can occur [7].

Muco-cutaneous lesions, while not uncommon, are not prominent in histoplasmosis as they are in paracoccidioidomycosis. In chronic disseminated histoplasmosis, ulcers in the tongue, hard palate and nasal septum may occur as a consequence of lymphohematic dissemination. Physicians of endemic areas such as Venezuela must consider histoplasmosis in the differential diagnosis of any chronic non-healing mucosal lesion [8].

We have observed upward trends in the number of cases with nasal septum perforation (NSP) due to disseminated histoplasmosis. In this matter, we decided to carry out a retrospective analysis of these cases.

\section{Material and Methods}

Study Design

We conducted a retrospective descriptive study of patients who developed NSP associated to histoplasmosis at the Medical Mycology Department “Dr. Dante Borelli”, Tropical Medicine Institute, Central University of Venezuela, Caracas, Venezuela.

\section{Data Collection}

Data collected included demographics, epidemiological, clinical and radiological features, diagnostic methods, treatment, and follow-up information from each case, as available in a 23-year period (from 1994 to 2017) from medical records of patients who attended to the Medical Mycology Department "Dr. Dante Borelli” referred from different health care centers in all the country. Data were collected on a standardized clinical report form. The diagnosis was made based on clinical manifestations and confirmed with mycological direct examination with Giemsa stain, culture, serologic tests (immunodiffusion method), and histopathology with hematoxylin-eosin, Grocott methenamine (GMS) and Periodic Acid-Schiff stain (PAS). Histopathological evaluation of all clinical specimens was performed at the Pathological Anatomy Institute “Dr. José Antonio O' Daly”, Central University of Venezuela. 
Patients fulfilled at least one of the following criteria: 1) Positive culture for Histoplasma sp. from nasal mucosa; 2) Demonstration of Histoplasma sp. by histopathology or cytology; and 3) Positive Histoplasma serology by double immunodiffusion with detection of $\mathrm{H}$ or $\mathrm{M}$ bands. Data regarding treatment, follow-up and outcome were included when available.

Data Analysis

Data were analyzed using IBM SPSS Statistics for Windows Software, version 20 (IBM Corp., Armonk, NY, USA). Descriptive statistics were used to calculate the absolute and relative frequencies and mean.

Ethical Considerations

This research was approved by the Independent Committee of Bioethics for Investigation from the Bioethics National Center, Protocol No. CIBI-CENABI-05-2020.

\section{Results}

Out of 1654 medical records reviewed with a diagnosis of histoplasmosis, we found 22 cases $(1.33 \%)$ having NSP. Of the 22 cases with NSP, 14 (63.6\%) were female and 8 (36.3\%) male. The age ranged from 20 to 98 years; with a mean age of 50.72 years, the most affected were between 20 and 39 years old ( 8 patients, 42.1\%). Most patients resided in urban areas (68.2\%), with most cases coming from the north-central endemic region of Venezuela. The rest of the patients came from other endemic areas of the country.

Eleven $(50 \%)$ patients had risk factors such as farming/gardening or cave tourism despite their occupations. Other risk factors observed were alcoholism $(9.1 \%)$ and $2(9.1 \%)$ patients were heavy smokers. In 7 cases $(31.8 \%)$ the data was missing (Table 1$)$.

Table 1. Distribution of participants according to sociodemographic characteristics.

\begin{tabular}{|c|c|c|}
\hline Variables & $\mathbf{N}$ & $\%$ \\
\hline \multicolumn{3}{|l|}{ Gender } \\
\hline Female & 14 & 63.6 \\
\hline Male & 8 & 36.4 \\
\hline \multicolumn{3}{|l|}{ Residence } \\
\hline Urban Area & 15 & 68.2 \\
\hline Rural Area & 5 & 22.7 \\
\hline Unknown & 2 & 9.1 \\
\hline \multicolumn{3}{|l|}{ Alcoholism } \\
\hline Yes & 2 & 9.1 \\
\hline No & 22 & 90.9 \\
\hline \multicolumn{3}{|l|}{ Smoking } \\
\hline Heavy Smoker & 2 & 9.1 \\
\hline No & 13 & 59.1 \\
\hline Missing & 7 & 31.8 \\
\hline \multicolumn{3}{|l|}{ Occupation Known } \\
\hline Farmer & 7 & 31.8 \\
\hline Builder & 1 & 4.5 \\
\hline Housewife & 5 & 22.7 \\
\hline Others & 7 & 31.8 \\
\hline Unknow & 2 & 9.1 \\
\hline
\end{tabular}


The most relevant clinical sign was septum perforation, observed in all 22 cases (100\%) (Figure 1), followed by epistaxis $(63.6 \%)$, crusting (54.5\%), dyspnea (40.9\%), fever $(18.1 \%)$, cough $(18.1 \%)$ and mucocutaneous manifestations (9\%) (nasal mucosa and skin). Other clinical manifestations such as headache, pain, rhinorrhea, cacosmia or foul smell, hepatic/splenomegaly, cervical adenomegaly and soft palate perforation was present in $6(27.2 \%)$ cases (Table 2$)$.

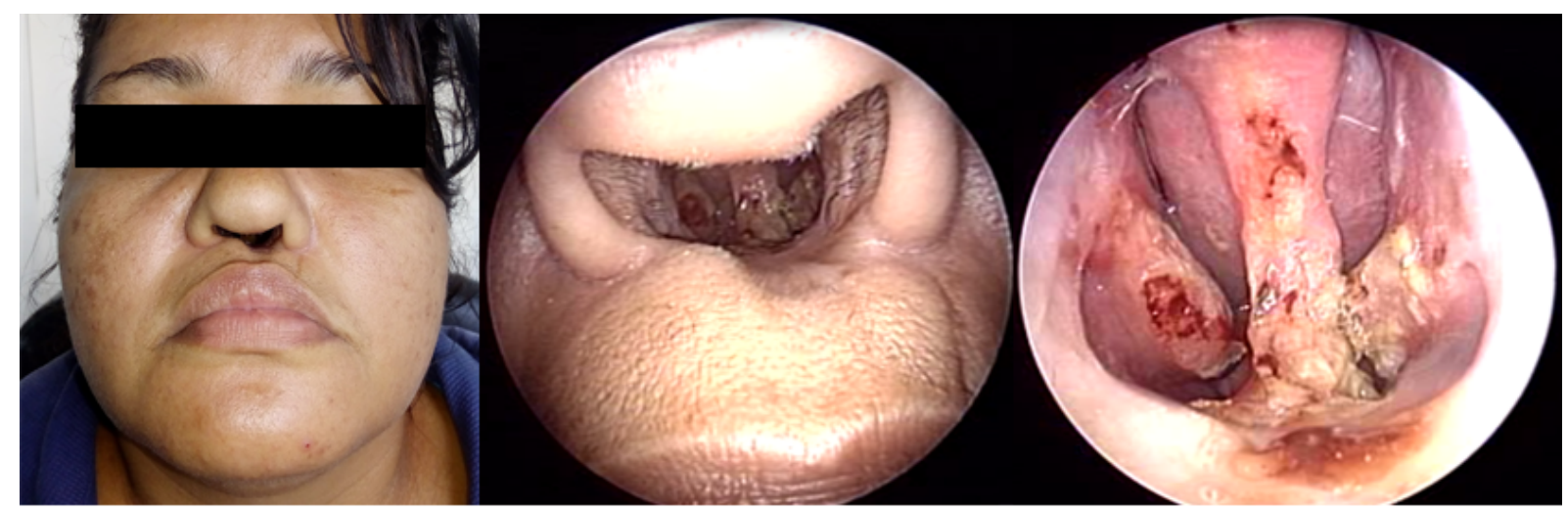

Figure 1. Clinical feature of NSP with fibroscopy.

Table 2. Distribution of participants according to signs and symptoms.

\begin{tabular}{ccc}
\hline Signs/Symptoms* & N & \% \\
\hline Epistaxis & 14 & 63.6 \\
Crustings & 12 & 54.5 \\
Fever & 5 & 22.7 \\
Dyspnoea & 6 & 27.2 \\
Cough & 3 & 13.6 \\
Others & 6 & 27.2 \\
\hline *Some patients had more than 1 sign/symptom &
\end{tabular}

Chest radiographs were available in $11(50 \%)$ patients. Seven $(31.8 \%)$ were reported as having diffuse bilateral interstitial pneumonitis. One patient had a tumor mass in the upper right lobe and pulmonary infiltrates in middle right lobe. In three patients, chest x-rays were reported as normal. Sinus CT-scan was performed in two patients $(10.5 \%)$ and revealed a perforation in the cartilaginous portion of nasal septum (Figure 2).

Autoimmune disease was present in 6 patients $(15.7 \%), 2(10.5 \%)$ had systemic lupus erythematosus (SLE), 2 (10.5\%) granulomatosis with polyangiitis, 1 (5.2\%) chronic kidney disease (CKD) and, 1 (5.2\%) chronic inflammatory response by an implant of biopolymers; all six were on immunosuppressive treatment (methotrexate, infliximab, and/or corticosteroids). Two patients (10.5\%) had HIV/AIDS, one of them (5.2\%) had also paracoccidiodomycoses (PCM); 1 patient (5.2\%) had diabetes mellitus (DM), 1 (5.2\%) arterial hypertension and the remaining 9 (47.3\%) cases had no apparent underlying disease or conditions (Table 3$)$. In all cases serology for HIV/AIDS was performed.

Complete laboratory tests were performed only in four patients. One of them showed pancytopenia, high erythrocyte sedimentation rate and abnormal hepatic tests. The remaining three (13.6\%) had no significant changes in laboratory studies.

Pulmonary manifestations were registered in six $(27.2 \%)$ cases whit abnormal chest X-ray. Three patients had CT head scans; Figure 2 showed the disruption in posterior portion of nasal septum (condrovomerian articulation). 


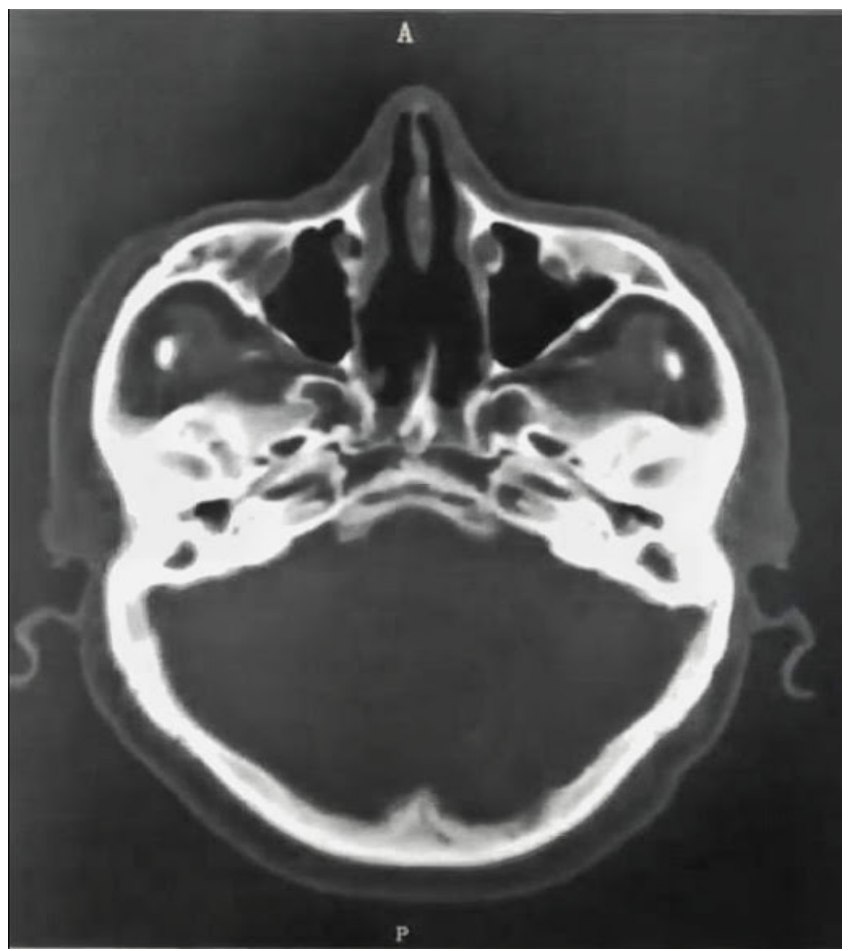

Figure 2. Axial cut of nose and paranasal sinus showing disruption in posterior portion of nasal septum (condro-vomerian articulation).

Table 3. Distribution of participants, according to comorbidities.

\begin{tabular}{lcc}
\hline \multicolumn{1}{c}{ Comorbidities } & N & \% \\
\hline HIV/AIDS & 2 & 9.1 \\
Lupus Erythematosus & 3 & 13.6 \\
Wegener Granulomatosis & 2 & 9.1 \\
Paracoccidioidomycoses & 2 & 9.1 \\
Arterial Hypertension & 2 & 9.1 \\
Diabetes & 2 & 9.1 \\
Chronic Renal Failure & 1 & 4.5 \\
None & 9 & 40.9 \\
\hline
\end{tabular}

In all cases, the diagnosis was achieved by direct examination of the samples with Giemsa stain and histopathological tissue exam. All the samples showed findings of inflammatory process; granulomatous response was observed in 18 (81.8\%) cases, and necrosis foci in 12 (54.5\%). The GMS and PAS stain revealed in all cases, small intracellular and extracellular yeast forms compatible with Histoplasma sp. (Figure 3). Culture and serology were performed in 8 patients, with $4(21 \%)$ resulting in a positive culture and one case $(4.5 \%)$ with a conclusive serology. For the remaining cases, data was missing.

Antifungal therapy was adequately registered for $14(63.6 \%)$ patients who received Itraconazole with an average duration of 12 months; 8 patients improved, 3 died and the other 3 were lost to follow-up. In one case $(4.5 \%)$, the infection was fulminant despite treatment with amphotericin B. This patient died due to delay in treatment by a misdiagnosis of tuberculosis. Multi-organic failure and respiratory distress were the cause of death in $4(18.1 \%)$ patients, including the aforementioned. One patient had HIV/AIDS and was lost to followup. Data about treatment was not available in 7 (31.8\%) cases. The seven (31.8\%) remaining patients were lost to follow- up (Table 4). Some patients were referred for surgical repair. 


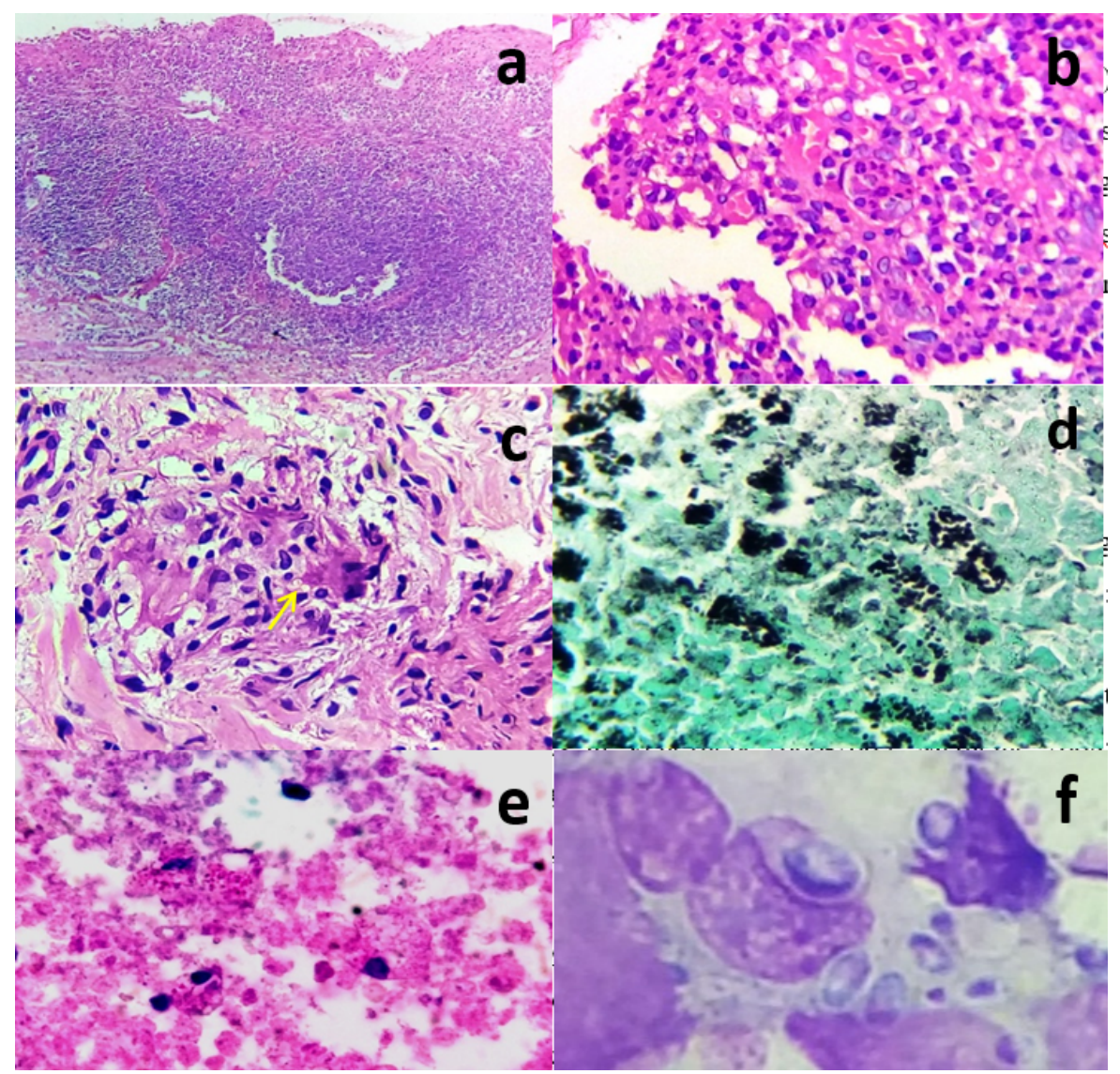

Figure 3. A and B: NSP border showed chronic inflammatory infiltrates (H\&E, X400 and X1000). C: Non-necrotizing granulomatous response giant cell with intracitoplasmatic yeast forms suggesting of Histoplasma sp. (yellow arrow, H\&E x1000). D: Multiple yeast forms suggesting of Histoplasma sp. (Gomori-Grocott x400). E: Multiple intracellular blastoconidias morphologically suggestive of Histoplasma sp. (PAS x400). F: Intracellular and extracellular blastoconidia morphologically suggestive of Histoplasma sp. (Diff-Quik ${ }^{\circledR}$ x1000).

\section{Discussion}

Histoplasmosis is the most common systemic mycosis worldwide [1,2,4]. It has a wide spectrum of clinical manifestations that mostly depends on the host immunological status and the fungal inoculum size [2,8-10]. After inhalation, conidia transform into yeast forms in the lungs, which are phagocyted by tissueresident macrophages. In the majority of cases, the yeasts are eliminated by the macrophages and the infection is either asymptomatic or mild and self-limiting. However, Histoplasma sp. limits its detection by pattern recognition receptors (PRR). The C-type lectin receptor dectine-1 is a major receptor for recognition of the $\beta$ glucans of the fungal cell wall. Most strains of Histoplasma sp. produce a layer of $\alpha$-linked glucans that overlies the $\beta$-glucans reducing its detection in the lung tissue. In patients whit faulty T-cell mediated immunity, the localized containment of the fungi does not occur and systemic dissemination via reticuloendothelial or hematogenous pathway take place. Approximately $10 \%$ of histoplasmosis cases develop progressive disseminated forms that can affect any organ, including muco-cutaneous lesions [2,8].

NSP is an uncommon clinical presentation of Histoplasma sp infection [11,12]. It may mimic other pathologies including trauma, autoimmune or immunosuppressing disorders (SEL, Rheumatoid Arthritis, etc.), infections (Syphilis, leishmaniasis, tuberculosis, leprosy and other fungal infections), neoplasia and other causes such as steroid or vasoconstrictor nasal spray usage, chronic cocaine abuse and chrome industry mining [13$18]$. 
Table 4. Distribution of participants according to clinical and epidemiological characteristics.

\begin{tabular}{|c|c|c|c|c|c|c|c|c|c|c|}
\hline No & Sex & Age (Years) & Risk Factors & $\begin{array}{c}\text { Clinical } \\
\text { Presentation }\end{array}$ & Lesions & Diagnosis & Treatment & Comorbidity & Chest X Ray & Follow up \\
\hline 1 & $\mathrm{~F}$ & 27 & Contact with landslide & $\begin{array}{c}\text { Epistaxis, nose } \\
\text { wound with crusts }\end{array}$ & NSP & $\begin{array}{l}\text { Biopsy, culture } \\
\text { and direct } \\
\text { examination }\end{array}$ & $\begin{array}{c}\text { Itraconazole } \\
\text { V.O } 400 \mathrm{mgs} \\
1 \text { year }\end{array}$ & None & $\begin{array}{c}\text { Interstitial } \\
\text { pneumonitis }\end{array}$ & Improvement \\
\hline 2 & $\mathrm{~F}$ & 20 & Farming & $\begin{array}{l}\text { Epistaxis, nose } \\
\text { wound with crusts, } \\
\text { cough, dyspnea, } \\
\text { weight loss, } \\
\text { cutaneous lesions }\end{array}$ & NSP & $\begin{array}{c}\text { Direct } \\
\text { examination }\end{array}$ & $\begin{array}{l}\text { Itraconazole } \\
\text { V.O } 400 \mathrm{mgs} \\
1 \text { year }\end{array}$ & $\begin{array}{c}\mathrm{HIV} / \mathrm{AIDS} \text { and } \\
\text { PCM }\end{array}$ & $\begin{array}{l}\text { Interstitial } \\
\text { pneumonitis }\end{array}$ & Dead \\
\hline 3 & $\mathrm{~F}$ & 27 & Barnyard fowl contact & $\begin{array}{l}\text { Epistaxis, cough, } \\
\text { dyspnea }\end{array}$ & NSP & Biopsy, culture & $\begin{array}{l}\text { Itraconazole } \\
\text { V.O } 400 \mathrm{mgs} \\
1 \text { year }\end{array}$ & None & $\begin{array}{l}\text { Interstitial } \\
\text { pneumonitis }\end{array}$ & Dead \\
\hline 4 & M & 38 & Cave tourism & $\begin{array}{l}\text { Epistaxis, productive } \\
\text { cough, dyspnea }\end{array}$ & NSP & $\begin{array}{l}\text { Biopsy and } \\
\text { direct } \\
\text { examination }\end{array}$ & $\begin{array}{l}\text { Itraconazole } \\
\text { V.O } 400 \mathrm{mgs} \\
1 \text { year }\end{array}$ & None & $\begin{array}{c}\text { Interstitial } \\
\text { pneumonitis }\end{array}$ & Improvement \\
\hline 5 & M & 73 & $\begin{array}{l}\text { Builder, treatment with } \\
\text { oral steroids and } \\
\text { methotrexate }\end{array}$ & $\begin{array}{l}\text { Epistaxis, nose } \\
\text { wound with crusts, } \\
\text { fever, dyspnea, nasal } \\
\text { discharge, cephalea }\end{array}$ & NSP & $\begin{array}{l}\text { Culture and } \\
\text { direct } \\
\text { examination }\end{array}$ & $\begin{array}{l}\text { Itraconazole } \\
\text { V.O } 400 \mathrm{mgs} \\
1 \text { year }\end{array}$ & $\begin{array}{c}\text { Granulomatosis } \\
\text { with } \\
\text { polyangiitis }\end{array}$ & $\begin{array}{l}\text { Interstitial } \\
\text { pneumonitis }\end{array}$ & Improvement \\
\hline 6 & M & 47 & $\begin{array}{l}\text { Farming, alcoholism, } \\
\text { barnyard fowl contact }\end{array}$ & $\begin{array}{l}\text { Nose wounds with } \\
\text { crusts, fever, adeno } \\
\text { and splenomegaly, } \\
\text { cough, dyspnea }\end{array}$ & NSP & $\begin{array}{l}\text { Culture and } \\
\text { direct } \\
\text { examination }\end{array}$ & $\begin{array}{l}\text { Itraconazole } \\
\text { V.O } 400 \mathrm{mgs} \\
1 \text { year }\end{array}$ & None & $\begin{array}{l}\text { Tumor mass } \\
\text { upper right lobe } \\
\text { and pulmonary } \\
\text { infiltrates }\end{array}$ & Improvement \\
\hline 7 & M & 98 & Unknown & Epistaxis & NSP & Biopsy & Unknown & None & Unknown & Unknown \\
\hline 8 & $\mathrm{~F}$ & 33 & $\begin{array}{l}\text { Treatment with anti- } \\
\text { TNF } \alpha\end{array}$ & Epistaxis & NSP & Biopsy & Unknown & SEL & Unknown & Unknown \\
\hline 9 & $\mathrm{~F}$ & 75 & Unknown & $\begin{array}{l}\text { Nose wounds with } \\
\text { crusts }\end{array}$ & NSP & Biopsy & Unknown & DM II & Unknown & Dead \\
\hline 10 & $\mathrm{~F}$ & 48 & Unknown & $\begin{array}{c}\text { Cacosmia, nose } \\
\text { wound with crusts }\end{array}$ & NSP & Biopsy & $\begin{array}{l}\text { Itraconazole } \\
\text { V.O } 400 \mathrm{mgs} \\
1 \text { year }\end{array}$ & SEL & Unknown & Unknown \\
\hline 11 & $\mathrm{~F}$ & 75 & Treatment with steroids & Epistaxis & NSP & Biopsy & Unknown & $\begin{array}{c}\text { Granulomatosis } \\
\text { with } \\
\text { polyangiitis }\end{array}$ & Unknown & Unknown \\
\hline
\end{tabular}




\begin{tabular}{|c|c|c|c|c|c|c|c|c|c|c|}
\hline 12 & $\mathrm{~F}$ & 29 & Unknown & $\begin{array}{l}\text { Nose wounds with } \\
\text { crusts }\end{array}$ & NSP & Biopsy & Unknown & HIV/AIDS & Unknown & Unknown \\
\hline 13 & M & 56 & Unknown & Epistaxis and pain & NSP & Biopsy & Unknown & Unknown & Unknown & Unknown \\
\hline 14 & $\mathrm{~F}$ & 78 & Treatment with steroids & Pain & NSP & Biopsy & Unknown & CKD & Unknown & Unknown \\
\hline 15 & $\mathrm{~F}$ & 39 & $\begin{array}{c}\text { Treatment with } \\
\text { Etanercept }^{\odot}(\mathrm{TNF} \alpha \\
\text { blocker })\end{array}$ & Epistaxis & NSP & Biopsy & $\begin{array}{l}\text { Itraconazole } \\
\text { V.O } 400 \mathrm{mgs} \\
1 \text { year }\end{array}$ & None & Normal & Improvement \\
\hline 16 & M & 49 & Contact with soil dust & $\begin{array}{c}\text { Epistaxis, nose } \\
\text { wound with crusts }\end{array}$ & NSP & Biopsy & $\begin{array}{l}\text { Itraconazole } \\
\text { V.O } 400 \mathrm{mgs} \\
1 \text { year }\end{array}$ & None & Normal & Improvement \\
\hline 17 & M & 51 & Poultry man & $\begin{array}{l}\text { Epistaxis, nasal } \\
\text { obstruction }\end{array}$ & NSP & $\begin{array}{c}\text { Direct } \\
\text { examination }\end{array}$ & $\begin{array}{c}\text { Itraconazole } \\
\text { V.O } 400 \mathrm{mgs} \\
1 \text { year }\end{array}$ & None & Normal & Improvement \\
\hline 18 & $\mathrm{~F}$ & 70 & Cave tourism, farming & $\begin{array}{c}\text { Epistaxis, nose } \\
\text { wounds with crusts, } \\
\text { dyspnea }\end{array}$ & NSP & $\begin{array}{l}\text { Serology, } \\
\text { culture and } \\
\text { biopsy }\end{array}$ & $\begin{array}{l}\text { Itraconazole } \\
\text { V.O } 400 \mathrm{mgs} \\
1 \text { year }\end{array}$ & AHT & $\begin{array}{c}\text { Interstitial } \\
\text { pneumonitis }\end{array}$ & Improvement \\
\hline 19 & $\mathrm{~F}$ & 20 & Farming & $\begin{array}{l}\text { Cacosmia, nose } \\
\text { wounds with crusts, } \\
\text { dyspnea, weight loss, } \\
\text { fever, hepato- } \\
\text { splenomegaly }\end{array}$ & $\begin{array}{l}\text { NSP and } \\
\text { palate } \\
\text { perforation }\end{array}$ & Biopsy & $\begin{array}{c}\text { Amphotericin } \\
\text { B }\end{array}$ & None & $\begin{array}{c}\text { Interstitial } \\
\text { pneumonitis }\end{array}$ & Dead \\
\hline 20 & $\mathrm{~F}$ & 47 & $\begin{array}{c}\text { Treatment with Treatment } \\
\text { with anti-TNF } \alpha \text {, heavy } \\
\text { smoker, barnyard fowl } \\
\text { contact }\end{array}$ & Epistaxis, fever & NSP & Biopsy & $\begin{array}{l}\text { Itraconazole } \\
\text { V.O } 400 \mathrm{mgs} \\
1 \text { year }\end{array}$ & LES & Unknown & Unknown \\
\hline 21 & $\mathrm{~F}$ & 70 & Cave tourism & $\begin{array}{l}\text { Wight loss, dyspnea, } \\
\text { crusting, rhinitis }\end{array}$ & NSP & Biopsy & $\begin{array}{c}\text { Itraconazole } \\
\text { V.O } 400 \mathrm{mgs} \\
1 \text { year }\end{array}$ & $\mathrm{PCM}$ & $\begin{array}{c}\text { Interstitial } \\
\text { pneumonitis }\end{array}$ & Unknown \\
\hline 22 & M & 46 & $\begin{array}{l}\text { Contact with soil dust, } \\
\text { smoker and alcoholism }\end{array}$ & $\begin{array}{l}\text { Wight loss, dyspnea, } \\
\text { crusting, hepato- } \\
\text { splenomegaly cervical } \\
\text { adenomegaly }\end{array}$ & NSP & Biopsy & $\begin{array}{l}\text { Itraconazole } \\
\text { V.O } 400 \mathrm{mgs} \\
1 \text { year }\end{array}$ & $\begin{array}{l}\text { DM II and } \\
\text { AHT }\end{array}$ & Unknown & Unknown \\
\hline
\end{tabular}


Why NSP occurs in histoplasmosis is unknown. The mechanisms related with this manifestation are complex and depend on the individual immune response. Host immune response toward fungal pathogens is initiated by the recognition of invading fungi via PRR expressed on antigen presenting cells. Receptormediated signaling induces downstream events such as cytokine and chemokine release, phagocytosis, and respiratory oxygen species (ROS) burst, ultimately leading to killing the fungus. In addition, the cytokine responses shape the induction of Th1 and Th17 adaptive immune response. IL 12 drives IFN-gamma production by T-helper 1 (Th1) cells, crucial for phagocytosis activation or avoid of immunological response $[6,19-22]$.

Macrophages of the innate branch of the immune system not only are ineffective in killing yeasts of Histoplasma sp. but also can behave as the principal host cell and vehicle for its dissemination. Once cellmediated immunity is triggered, Th1-cytokine signals (e.g., tumor necrosis factor alpha [TNF-] and gamma interferon [IFN-]) activate phagocytic cells and potentiate their antifungal mechanisms [4,6,23].

In this study, we found patients that were farmers and housewives with a history of farming/gardening or cave tourism, builders exposed to roost droppings, also patients who frequently traveled around the country and were exposed to climatic changes and elderly patients (70-98 years old) among others. These conditions have been commonly implicated as risk factors for histoplasmosis [2,4,8,9].

Histoplasmosis is acquired through the respiratory route. The acquisition is related to human activities and climatic conditions that increase the risk of exposure to these organisms in susceptible individuals. Factors such as intense urbanization and climatic changes may cause the fungi's ecological impairment, leading to dispersion of the conidia, which could be inhaled by exposed individuals. Additionally, there are other sources for exposure to Histoplasma sp., including lumberjacking, street-swipping, and dovecotes cleansing, such as attics as suggested elsewhere. Considering the occupation of patients at the moment of the diagnosis may give an important epidemiological clue of risk factors $[1,2,4,5,8,9]$.

The clinical manifestations we found were mainly NSP, along with epistaxis in $63.6 \%$ cases, crusting $(54.5 \%)$, dyspnea (27.2\%), fever (22.7\%), cough (13.6\%), and $9 \%$ had muco-cutaneous manifestations (nasal mucosa and skin). Other symptoms reported included nasal obstruction, rhinorrhea, chronic rhinosinusitis and pain. One of our patients had soft palate perforation. Pulmonary manifestations were registered in six cases whit abnormal chest X-ray. These findings are similar to what is described in the literature [12,24-30].

As aforementioned, NSP clinical manifestations could be variable being sometimes an occasional finding in the rhinoscopy [31]. It has multiple causes being its physiopathological basis a mucosal and perichondrium lesion with local blockage of the blood supply. Blood irrigation of the nasal septum arises from maxillary artery branches, which converge to the muco-perichondrial leaflets that covers each side of the septal cartilage. Any threat to the vascularity of these leaflets can jeopardize the underlying cartilage, predisposing to septal perforation. This condition disturbs the nasal airflow, and creates turbulence, which causes mucosal dryness that predisposes scabbing and epistaxis. Unfortunately, deformity of the nasal dorsum is noticed when large perforation occurs and can threaten dorsal nasal support. The local inflammation may cause granulation tissue or excessive crusting. An intraoral exam can rule out palatal involvement [11]. Thus, cases with perforation of the nasal septum and scabbing ulcers should suggest the possibility of histoplasmosis.

In our study, we found six patients who were receiving immunosuppressive drugs as methotrexate, infliximab, corticosteroids, to treat various clinical conditions such as SEL, granulomatosis with polyangiitis, chronic renal failure, and chronic inflammatory response by biopolymer implants. This observation is consistent with other authors who described 7 cases of disseminated histoplasmosis in patients with autoimmune disorders receiving immunosuppressant agents, two of them with NSP [24]. Another multicenter 
study with 98 patients with histoplasmosis was considered, all with concomitant autoimmune disorders and tumor necrosis factor alpha blocker $(\mathrm{TNF}-\alpha)$ therapy, but none of them had NSP [32].

Although TNF- $\alpha$ blocker therapy has revolutionized the treatment of several autoimmune disorders, the use of immunosuppressive medications such as TNF- $\alpha$ blockers has resulted in a rising trend of histoplasmosis, since this cytokine plays a critical role in the host's immune response to Histoplasma sp [30,32,33]. Ideally, healthcare providers should be able to suspect and diagnose histoplasmosis in an endemic area such as Venezuela, in any condition being treated with this kind of therapy.

Although histoplasmosis is usually seen in immunocompromised patients, in 9 of our cases, there was no evidence of immunosuppression. Primary immunodeficiencies (PID) in Venezuela are rarely diagnosed, and recognition of those who may have underlying PID could be a challenge [2]. Also, individuals who are apparently healthy may develop histoplasmosis, but it is important to bear in mind that malnutrition and stress due to the political situation in our country could have an influence in the immune response of the host. Also, in Venezuela, currently, health centers lack diagnostic tools, possibly leading to misdiagnosis in many patients, with the consequence of an upraise in the morbidity and mortality of the disease. Defects of T-cell development and differentiation, phagocytic functions and pathways involved in innate recognition and downstream signaling, have been associated with increasing cases of histoplasmosis [4]. Therefore, individuals who are apparently healthy could also develop histoplasmosis. Two of our cases had HIV/AIDS, both were females, of 20 and 29 years old, respectively. The first of them also had PCM with respiratory manifestations and abnormal findings in the chest radiograph and died. The other case was lost to follow up.

Human immunodeficiency virus infection is the most common cause of dissemination or extrapulmonary forms of histoplasmosis. It is considered an (AIDS) - defining illness in the world [4,34,35]. In Venezuela, histoplasmosis occurs in up to $39 \%$ of HIV infected patients and represents the first manifestation of AIDS in up to $50-70 \%$ of patients, causing a high rate of morbidity. Due to the lack of diagnostic facilities and algorithms, histoplasmosis is underdiagnosed in many HIV patients and it is considered an "invisible burden" of AIDS in our country [35].

Almost all studies in the international literature, report NSP in patients with HIV/AIDS. A recent case report and literature review showed a Haitian female with HIV/AIDS and nasal septum destruction along with another 18 cases, almost all have HIV/AIDS [25]. The same data has been reported elsewhere $[26,28,29]$.

Due to the small size of the fungus $(2-4 \mu \mathrm{m})$, the histoplasmosis diagnosis is usually done by isolation in culture. This process can take a long time and may delay the diagnosis and treatment [12]. Although culture is the gold standard diagnostic test, it takes up to four weeks to provide conclusive results. Thus, in severe cases, when prompt intervention is required, it may not be effective. Additionally, a fungal culture is positive in only approximately $25 \%$ to $40 \%$ of the cases. In severe chronic lesions, GMS staining allows visualization of the infectious agent and aids in diagnosis. Therefore, the histopathological exam is a very important tool. In our cases, the thorough search and review by well-trained personnel, allowed us to successfully found the small intracellular yeast of Histoplasma sp. in all samples reviewed. In some of the cases, it was the first positive result given to the patient, which allowed appropriate treatment in a short time $[2,8,34]$.

This study had some limitations. Being a retrospective and descriptive analysis, we lacked specific data that were not collected for each patient. Since we managed not all patients, procedures of data collection, sample taking, treatment, and follow up of the patients were not uniform. Although missing data may partly 
compromise the study's conclusions, the importance of clinical manifestations, diagnosis, treatment, and outcome of the patients is not overruled.

\section{Conclusion}

Suspicion and diagnosis of Histoplasma sp. in patients who present with nasal-perforation and risk factors for the disease, is of utmost importance. Such knowledge will allow us to better understand its epidemiology, clinical patterns and response to treatment.

\section{Authors' Contributions}

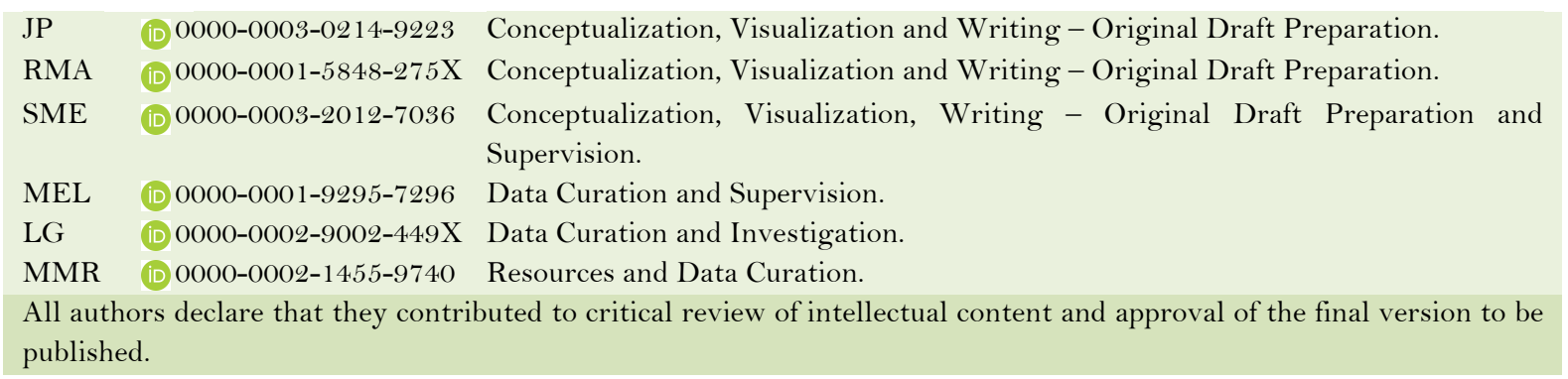

\section{Financial Support}

None.

\section{Conflict of Interest}

The authors declare no conflicts of interest.

\section{References}

[1] Bahr N, Antinori S, Wheat L, Sarosi G. Histoplasmosis infections worldwide: thinking outside of the Ohio River Valley. Curr Trop Med Rep 2015; 2(2):70-80. https://doi.org/10.1007/s40475-015-0044-0

[2] Mata-Essayag S, Colella MT, Roselló A, de Capriles CH, Landaeta ME, de Salazar CP, et al. Histoplasmosis: a study of 158 cases in Venezuela 2000-2005. Medicine 2008; 87(4):193-202. https://doi.org/10.1097/MD.obo13e31817fa2a8

[3] Martínez D, Hernandez R, Alvarado P, Mendoza M. Las micosis en Venezuela: casuística de los grupos de trabajo en micología (1984-2010). Rev Iberoam Micol 2013; 30(1):39-46. https://doi.org/10.1016/j.riam.2012.10.001 [In Spanish]

[4] Lee PP, Lau Y-L. Cellular and molecular defects underlying invasive fungal infections- revelations from endemic mycoses. Front Immunol 2017; 8:735. https://doi.org/10.3389/fimmu.2017.00735

[5] Sifuentes J, Corzo D, Ponce L. Epidemiology of invasive fungal infections in Latin America. Curr Fungal Infect Rep 2012; 6(1):23-4. https://doi.org/10.1007/s12281-011-0081-7

[6] Garfoot A, Rappleye C. Histoplasma capsulatum surmounts obstacles to intracellular pathogenesis. FEBS J 2016; 283(4):619-33. https://doi.org/10.1111/febs.13389

[7] Kasuga T, Taylor JW, White TJ. Phylogenétic relationships of varieties and geographical groups of the human pathogenic fungus histoplasma capsulatum darling. J Clin Microbiol 1999; 37(3)653-63.

[8] Merino-Alado R, Mata-Essayag S, Pineda J, Moronta G, Briceño EN, et al. Oral manifestations associated to paracoccidioidomicosis and histoplasmosis. Pesqui Bras Odontopediatria Clin Integr 2018, 18(1):e3846. https://doi.org/10.4034/PBOCI.2018.181.07

[9] Ajello L. Observations on the epidemiology of histoplasmosis. Mycopathol Mycol Applic 1961; 15:231-7.

[10] Gilbert AS, Wheeler RT, May RC. Fungal pathogens: survival and replication within macrophages. Cold Spring Harb Perspect Med 2015; 5(7):a019661. https://doi.org/10.1101/cshperspect.a019661

[11] Fornazieri M, Moreira JH, Pilan R, Voegels RL. Perforation of nasal septum: etiology and prognosis. Int Arch Otorhinolaryngol 2010; 14(4):467-71.

[12] Manzini M, Lavinsky-Wolff M. Nasal histoplasmosis without lung involvement in an immunocompromised patient. Braz J Otorhinolaryngol 2012; 78(5):136. https://doi.org/10.5935/1808-8694.20120022 
[13] Rodríguez G, Sarmiento LZ, Hernández CA. Leishmaniasis mucosa y otras lesiones destructivas centrofaciales. Biomedica 1994; 14:215-29. https://doi.org/10.7705/biomedica.v 14i4.2 108 [In Spanish]

[14] Sood N, Gugnani HC, Batra R, Ramesh V, Padhye AA. Mucocutaneous nasal histoplasmosis in an immunocompetent young adult. Indian J Dermatol Venereol Leprol 2007; 73(3):182-4. https://doi.org/10.4103/0378-6323.32743

[15] Roverano S, Gallo J, Ortiz A, Paira S. Manifestaciones sistémicas asociadas al consumo de cocaína: comunicación de un caso. Rev Arg Reumatol 2016; 27(3):50-2. [In Spanish]

[16] Keyserling HF, Grimme JD, Camacho DL, Castillo M. Nasal septal perforation secondary to rhinitis medicamentosa. Ear Nose Throat J 2006; 85:376(378-9).

[17] Bolek EC, Erden A, Kulekci C, Kalyoncu U, Karadag O. Rare occupational cause of nasal septum perforation: nickel exposure. Intern J Occup Med Environm Health 2017; 30(6):963-7. https://doi.org/10.13075/ijomeh.1896.01019

[18] Hage C, Bowyer S, Tarvin S, Helper D, Kleiman M, Wheat L. Recognition, diagnosis, and treatment of histoplasmosis complicating tumor necrosis factor blocker therapy. Clin Infect Dis 2010; 50(1):85-92. https://doi.org/10.1086/648724

[19] Horwath MC, Fecher RA, Deepe Jr GS. Histoplasma capsulatum, lung infection and immunity. Future Microbiol 2015; 10(6):967-75. https://doi.org/10.2217/fmb.15.25

[20] Radu M, Nosanchuk J. Histoplasma virulence and host responses. Inter J Microbiol 2012; 2012:268123. https://doi.org/10.1155/2012/268123

[21] Holbrook E, Smolnycki K, Youseff B, Rappleye C. redundant catalases detoxify phagocyte reactive oxygen and facilitate histoplasma capsulatum pathogenesis. Infect Immun 2013; 81(7):2334-46. https://doi.org/10.1128/IAI.00173-13

[22] Deepe Jr GS, Gibbons R. Interleukins 17 and 23 Influence the host to histoplasma capsulatum. J Infect Dis 2009; 200(1):142-51. https://doi.org/10.1086/599333

[23] Pagan A, Ramakrishnan L. The formation and function of granulomas. Annu. Rev Immunol 2018; 36:639-65. https://doi.org/10.1146/annurev-immunol-032712-100022

[24] Negri M, Gontero R, Benavente E, Zunino A, Ceccato F, Paira S. Manifestaciones inusuales de histoplasmosis en enfermedades del tejido conectivo. Rev Arg Reumatol 2012; 23(2):26-39. [In Spanish]

[25] Lehur AC, Zielinski M, Pluvy J, Grégoire V, Diamantis S, Bleibtreu A, et al. Case of disseminated histoplasmosis in a HIV-infected patient revealed by nasal involvement with maxillary osteolysis. BMC Infect Dis 2017; 17:328. https://doi.org/10.1186/s12879-017-2419-4

[26] Jaimes A, Muvdi S, Alvarado Z, Rodríguez D. Perforation of the nasal septum as the first sign of histoplasmosis associated with AIDS and review of published literature. Mycopathologia 2013; 176(1-2):145-50. https://doi.org/10.1007/s1 1046-013-9662-z

[27] Rizzi MD, Batra PS, Prayson R, Citardi MJ. Nasal histoplasmosis: report of a case. Otolaryngol - Head Neck Surg 2006; 135(5):803-4. https://doi.org/10.1016/j.otohns.2005.02.017

[28] Francini B, Cánepa MC, Lamonica C, Capece P, Posse G, Sanguineri V, et al. Histoplasmosis diseminada. Una infección oportunista en pacientes con infección por VIH. Experiencia en el Hospital Nacional Prof. A. Posadas, 20112017. Rev Chilena Infectol 2018; 35(6):671-9. https://doi.org/10.4067/So7 16-10182018000600671 [In Spanish]

[29] Felix F, Gomes GA, Linhares Pinto P, Migueres A., Da Penha Costa M, Tomita S. Nasal histoplasmosis in the acquired immunodeficiency syndrome. J Laryngol Otol 2006; 120:67-9. https://doi.org/10.1017/So022215105006432

[30] Pedroso MCM, Araujo AB, Crespo AN, Sampaio MH, Sakano E. Nasal septum ulcer as an isolated manifestation of histoplasmosis. IDCases 2019; 15:e00490. https://doi.org/10.1016/j.idcr.2019.e00490

[31] Gerber ME, Rosdeutscher JD, Seiden AM, Tami TA. Histoplasmosis: the otolaryngologist's perspective. Laryngoscope 1995; 105(9 Pt 1):919-23. https://doi.org/10.1288/00005537-199509000-00009

[32] Vergidis P, Avery RK, Wheat LJ, Dotson JL, Assi MA, Antoun SA, et al. Histoplasmosis complicating tumor necrosis factor-? blocker therapy: a retrospective analysis of 98 cases. Clin Infect Dis 2015; 61(3):409-17. https://doi.org/10.1093/cid/civ299

[33] Beltran O, Tona G. Papel del Otorrrinolaringólogo en el diagnóstico y seguimiento de pacientes con vasculitis primarias. Reumatol Clin 2011; 7(S3):S7-S11. https://doi.org/10.1016/j.reuma.2011.10.002 [In Spanish]

[34] Murray A, McGarry G. The clinical value of septal perforation biopsy. Clin Otorhinolaryngol 2000; 25(2):107-9. https://doi.org/10.1046/j.1365-2273.2000.00332.x

[35] Landaeta-Nezer ME, Mata-Essayag S, Colella MT, Pineda V, Rosello A. Histoplasmosis in AIDS patients in Venezuela. J J AIDS HIV 2015; 1(1):006. 